\title{
Hand hygiene promotion in long-term care facilities (LTCF) - a cluster randomized controlled trial
}

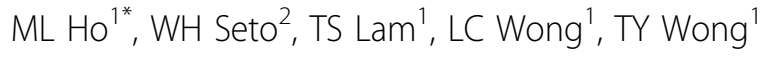 \\ From International Conference on Prevention \& Infection Control (ICPIC 2011) \\ Geneva, Switzerland. 29 June - 2 July 2011
}

\section{Introduction / objectives}

This is the 1st cluster randomized controlled trial showing effectiveness of WHO Multimodal Strategy in promoting hand hygiene $(\mathrm{HH})$ among health care workers (HCW) of LTCF with only 1 registered nurse per home at one time.

\section{Methods}

18 elderly homes with a total of $812 \mathrm{HCW}$ were randomly allocated to 2 intervention arms and a control arm. The study was conducted during November 2009 to July 2010. WHO Multimodal Strategy was employed, homes under interventional arms I and II were supplied with slightly powdered gloves and powderless gloves respectively. Controls were provided with similar promotion materials unrelated to $\mathrm{HH}$. Direct observation by trained nurses was used to measure $\mathrm{HH}$ compliance. Self-administered questionnaires served to assess $\mathrm{HH}$ knowledge of HCW. Disease notification data during 2007-2010 were used to calculate incidence rate ratio (IRR).

\section{Results}

A total of 11,669 HH opportunities were observed. $\mathrm{HH}$ compliance increased from $27.0 \%$ to $60.6 \%$ and from $22.2 \%$ to $48.6 \%$ in intervention arms I and II respectively. Both intervention arms showed increase in $\mathrm{HH}$ compliance after intervention compared to controls of $21.6 \%$ (both $\mathrm{p}<0.001$ ). "Before touching patient" among the WHO five moments for $\mathrm{HH}$, activity index $>40$ opportunities/hour, physiotherapist/occupational therapist were associated with less improvement. Mean knowledge

${ }^{1}$ Centre for Health Protection, Hong Kong, China

Full list of author information is available at the end of the article score increased from 5.5 to 6.6 after intervention. Respiratory outbreaks (IRR $=0.12$; 95\% CI: 0.01-0.93; $\mathrm{p}=0.04)$ and MRSA admissions (IRR $=0.61 ; 95 \% \mathrm{CI}$ : 0.38 $0.97 ; \mathrm{p}=0.04)$ reduced after intervention.

\section{Conclusion}

Promotion program applying WHO Multimodal Strategy is effective in improving $\mathrm{HH}$ among $\mathrm{HCW}$ in LTCF.

\section{Disclosure of interest}

None declared.

\section{Author details}

${ }^{1}$ Centre for Health Protection, Hong Kong, China. ${ }^{2}$ Hospital Authority, Hong Kong, China.

Published: 29 June 2011

doi:10.1186/1753-6561-5-S6-O65

Cite this article as: Ho et al:: Hand hygiene promotion in long-term care facilities (LTCF) - a cluster randomized controlled trial. BMC Proceedings 2011 5(Suppl 6):065.

Submit your next manuscript to BioMed Central and take full advantage of:

- Convenient online submission

- Thorough peer review

- No space constraints or color figure charges

- Immediate publication on acceptance

- Inclusion in PubMed, CAS, Scopus and Google Scholar

- Research which is freely available for redistribution 